\title{
Morphological and Cultural Studies of Peziotrichum corticolum (Massee) Subramanian Causing Black Banded Disease of Mango
}

\author{
Chirag Gautam*, H. Virupaksha Prabhu and V.B. Nargund \\ Department of Plant Pathology, University of Agricultural Sciences, \\ Dharwad, 580005, Karnataka, India \\ *Corresponding author
}

\begin{tabular}{|c|c|}
\hline & A B S T R A C T \\
\hline Keywords & \multirow{4}{*}{$\begin{array}{l}\text { Black banded disease of mango, caused by Peziotrichum corticolum (Massee) } \\
\text { Subramanian, is becoming severe for the last three to four years in all the } \\
\text { mango growing regions. Morphological and cultural characteristics of the } \\
\text { pathogen were studied. The identity of the fungus was confirmed. The fungus } \\
\text { showed maximum radial growth on host extract dextrose agar on } 12^{\text {th }} \text { day after } \\
\text { incubation at } 27 \pm 1^{\circ} \mathrm{C} \text {. Culture of } P \text {. corticolum exhibited diversity with respect } \\
\text { to cultural characters like type of the growth, mycelial colour, pigmentation } \\
\text { and colony margin. Maximum dry mycelial weight of the fungus was recorded } \\
\text { on } 14^{\text {th }} \text { day after incubation. Dry mycelial weight of the fungus was more in } \\
\text { Richards' broth }(538.00 \mathrm{mg}) \text { than potato dextrose broth }(442.33 \mathrm{mg}) \text {. }\end{array}$} \\
\hline $\begin{array}{l}\text { Black banded } \\
\text { disease, Mango, } \\
\text { Peziotrichum } \\
\text { corticolum, } \\
\text { Cultural, } \\
\text { Morphological. }\end{array}$ & \\
\hline Article Info & \\
\hline $\begin{array}{l}\text { Accepted: } \\
\text { 12 March } 2017 \\
\text { Available Online: } \\
10 \text { April } 2017\end{array}$ & \\
\hline
\end{tabular}

\section{Introduction}

In the basket of Indian fruit market, mango (Mangifera indica L.) shares a big place. It is described as the "king of fruits" or "super fruit" and known for its strong aroma, delicious taste and high nutritive value. It belongs to the family Anacardiaceae. It is considered to be originated in Indo-Burma region. Mango is a most important crop among the tropical and sub tropical fruit crops. India ranks first among world's mango producing countries accounting for $2.51 \mathrm{mha}$ area having an annual production of $18.43 \mathrm{mt}$ with the productivity of $7.3 \mathrm{t} / \mathrm{ha}$. Mango crop contributes $20.7 \%$ production share of major fruit crops in India. In Karnataka, the area under mango cultivation is 1.80 lakh ha with a production of $1.75 \mathrm{mt}$ and productivity of 9.7 t/ha (National Horticultural Database, 2014).

Although India is the largest producer of mango, the productivity is low. This may be due to the wide range of climatic conditions, environmental situation in which the mango grows and the diversity of the associated disease problems. There are more than 140 diseases, insect pests and physiological disorders, known to cause damage to the crop at all stages of its development, right from the plant in the nursery to the fruit in storages or transit, yet there are few diseases which are of great economic importance (Om Prakash, 1998). 
Earlier black banded disease of mango was considered as a minor disease but for the last three to four years it is becoming severe in all the mango growing regions. The causal fungus Peziotrichum corticolum (Massee) Subramanian was described on the bark of trees in Poona, India by Massee (Hughes, 1980). Later on, it has been reported from Goa, West Bengal, Karnataka, Maharashtra, Bihar, Orissa, Andhra Pradesh, Kerala, Andaman \& Nicobar Islands and Tamil Nadu in mild to severe form (Naqvi, 2004; Ploetz and Om Prakash, 1997 and Om Prakash and Srivastava, 1987).

The pathogen grows superficially on the bark of trees forming large, dark black, irregular, girdle-like infection patches and hence the name. Pandey and Dinesh (2010) found black velvety growth of fungus on the midribs and veins of leaves also (Pandey and Dinesh, 2010).

As the information available on the causal fungus Peziotrichum corticolum is very less, morphological and cultural studies were conducted in this present study.

\section{Materials and Methods}

The present investigations on black banded disease of mango were conducted during 2014-2015 at the Department of Plant Pathology, College of Agriculture, University of Agricultural Sciences, Dharwad. It is situated in northern transitional zone (Zone 8) of Karnataka state at $15^{\circ} 15^{\prime} \mathrm{N}$ latitude, $75^{\circ} 7^{\prime} \mathrm{N}$ longitude and at an altitude of 774.0 $\mathrm{m}$ above mean sea level. The materials used and methodology adopted during the course of investigations are presented here.

\section{Collection and isolation of the pathogen}

The twigs of mango (Mangifera indica L.) showing the typical symptoms of the disease were collected from silver jubilee orchard, Main Agricultural Research Station, University of Agricultural Sciences, Dharwad. The standard tissue isolation procedure was followed to isolate the pathogen. The infected bark bits were surface sterilized with sodium hypochlorite (1.0\%) solution for 60 seconds. These bits were thoroughly washed in sterile distilled water to remove the traces of sodium hypochlorite if any, then aseptically transferred to sterilized Petri plates (1-2 bits of infected bark portion per Petri dish) containing Potato Dextrose Agar (PDA). The Petri plates were incubated at room temperature $\left(27 \pm 1^{0} \mathrm{C}\right)$ and observed periodically for the growth. Bit of fungal growth developed from the infected tissue was transferred to PDA slants and incubated at $27^{0} \pm 1^{0} \mathrm{C}$ for 12 days. Then such slants with pure culture were used for further studies.

\section{Identification of the pathogen}

Identification of Peziotrichum corticolum was achieved by studying morphological characters of the same pathogen as described by Mukherjee and Litz (2009) and Patil and Dangat (2012). Koch postulates were proved to identify and to confirm the pathogenicity of isolated pathogen.

\section{Maintenance of the cultures}

The fungus was sub-cultured on Potato dextrose agar (PDA) slants and allowed to grow at $27 \pm 1^{\circ} \mathrm{C}$ for 16 days, such slants were preserved in refrigerator at $5^{\circ} \mathrm{C}$ and maintained.

Sub-culturing was done once in a month, such cultures were used throughout the study; virulence of the fungus was maintained by passing through the host after every three months. 


\section{Proving the pathogenicity}

Mango seedlings of aged three to four years were grown in the earthen pots filled with sterilized soil. Pathogenic culture of $P$. corticolum was grown on PDA for 15 days. Injury on seedlings was made by removing upper layers of the bark with the help of a sharp, sterilized knife. With sterilized spatula, mycelial disc was inoculated on the injury. Then the inoculated area was added with small quantity of sterile distilled water and covered with the help of transparent adhesive tape. Two controls were maintained as explained here under.

Control I: Injury + media + sterile distilled water

Control II: Sterile distilled water

All plants were covered with polythene bags for $48 \mathrm{hr}$ to maintain humidity. After $48 \mathrm{hr}$ of incubation, polythene bags were removed and the plants were kept in greenhouse. Observations were made for symptom development periodically. Re-isolation was made from the spots which were showing typical symptoms on inoculated plants. The isolated culture was compared with the original culture to confirm the pathogen.

\section{Cultural characteristics of $\boldsymbol{P}$. corticolum on different solid media}

Dharwad isolate of $P$. corticolum was grown on different media viz., Potato dextrose agar, Host extract dextrose agar, Czapek's malt agar, Richards' agar, Oat meal agar, V-8 juice agar and Potato carrot agar and observations were recorded for colony characters viz., radial growth in $(\mathrm{mm})$, colour, type of growth, pigmentation, colony margin and sporulation of the pathogen, when the maximum growth was attained on any one of the tested media. The composition and preparation of the above mentioned synthetic and semisynthetic media were obtained from Ainsworth and Bisby's 'Dictionary of the Fungi' by Ainsworth (1971) and plant pathological methods, fungi and bacteria by Tuite (1969).

For Host extract dextrose agar (HEDA), bark from the healthy green twigs was peeled $(200.0 \mathrm{~g})$ and boiled in $500 \mathrm{ml}$ water for 30 min. Extract was collected by filtering through muslin cloth. Dextrose (20 g) was added in this extract and mixed well. The agar agar was melted in $500 \mathrm{ml}$ water. Both the solutions were mixed and the volume was made up to $1000 \mathrm{ml}$ and then autoclaved at $1.1 \mathrm{~kg} / \mathrm{cm}^{2}$ pressure for 15 minutes at $121^{\circ} \mathrm{C}$.

\section{Cultural characteristics of $\boldsymbol{P}$. corticolum on liquid media}

Two liquid media namely, potato dextrose broth and Richards' broth were used to study growth phase of $P$. corticolum. The composition and preparation of both liquid media used were the same as that of solid media except that the agar was not added. Thirty $\mathrm{ml}$ of broth was added into each of 100 $\mathrm{ml}$ conical flask and sterilized at $1.1 \mathrm{~kg} / \mathrm{cm}^{2}$ pressure for 15 minutes at $121^{\circ} \mathrm{C}$. After sterilization, these flasks were allowed to cool and then inoculated with $5 \mathrm{~mm}$ disc from 15 days old culture and incubated at room temperature. Each treatment was replicated three times. The culture was filtered through Whatman No. 42 filter paper of $9.0 \mathrm{~cm}$ diameter, which was dried to a constant temperature at $60^{\circ} \mathrm{C}$ in an electric oven prior to filtration. The mycelial mat on the filter paper was thoroughly washed with sterile distilled water to remove traces of salts likely to be associated with it. Three flasks were harvested at $48 \mathrm{hrs}$ after incubation and subsequent harvesting was done at an interval of two days up to 20 days. The filter paper along with the mycelial mat were dried to a constant weight at $60^{\circ} \mathrm{C}$ and weighed 
immediately on a digital balance. The difference between final and initial weight of filter disc was taken as the weight of the mycelial mat. The data were analyzed statistically.

Dry mycelial weight $(\mathrm{mg})=$ Total weight of filter paper along with mycelia - Initial weight of filter paper

\section{Spore Morphology}

The spores produced in the black velvety growth of fungus on the host bark were observed. Length and breadth of spores were measured using motic images in computer $(400 \mathrm{X})$. The average size of the spore was calculated.

\section{Results and Discussion}

\section{Symptomatology}

The typical black banded symptoms were observed on twigs, branches, leaf petiole, midrib and veins of leaves. Symptoms were rarely produced on main trunk of the tree. Inflorescences were found to be free from symptoms. On branches and twigs, symptoms are characterized by typical black, irregular, superficial velvety fungal growth. The size of fungal growth increased with the advancement of the disease which resulted in large, black coloured, girdle like velvety bands. Velvety appearance of bands is due to fungal mycelium which aggregate together and erect, perpendicular to bark.

The young spreading mycelium near the periphery of the infection bands is white or nearly hyaline. In infected trees, symptoms are more conspicuous on young branches and twigs than on old branches. The velvety mycelial growth drops off in the summer months leaving light black coloured, bands in the affected portions. On leaves, black velvety fungal growth can be seen on midrib and veins. Girdling of petioles by black velvety fungal growth is also common (Fig. 1).

\section{Proving pathogenicity}

Fungus was isolated from infected bark of mango tree and pure culture was obtained by subsequent sub-culturing and such culture was used for pathogenecity test as described in "Material and Methods" (Fig. 2).

On tenth day of inoculation, typical black velvety fungal growth was seen on twigs. On $13^{\text {th }}$ day, area between velvety fungal growths became black. The boundary of black fungal growth was light white in colour. The fungus was reisolated and pathogenic culture thus obtained was compared with the original culture of $P$. corticolum.

\section{Identification of the pathogen}

Identification of the fungus was carried out based on the morphological characters of the isolated fungus. The fungus in the present study produced septate mycelium. Isolated fungal culture was white. After twenty days, white colour changed to brown and subsequently black colour. Fungal hypha was white in early days later it changed to brown colour (Fig. 3).

\section{Morphological and cultural studies of the pathogen}

\section{Spore morphology}

In the present study, conidia of $P$. corticolum obtained from infected bark were measured and compared with respect to their spore morphology. The conidia were single-celled, pale brown, globose, smooth-walled and measured 11.25 - $17.36 \mu$ in diameter. Further conidia were transferred to water agar and germination of conidia was observed (Fig. 3). 


\section{Mycelium morphology}

Mycelium of $P$. corticolum obtained from infected bark and culture was septate, brown in colour and measured $3.2-6.82 \mu$ in width (Fig. 3).

\section{Cultural characteristics of $\boldsymbol{P}$. corticolum on different solid media}

Diversity in cultural and morphological characters of $P$. corticolum were studied in five non synthetic / semi synthetic and two synthetic media at room temperature $27 \pm 1^{\circ} \mathrm{C}$ as described in materials and methods. Colony characters and sporulation of the fungi were recorded, when the maximum growth was attained on any one of the tested media. The effect of different culture media on the growth of fungi differed significantly.

Maximum radial growth of $P$. corticolum was recorded on host extract dextrose agar $(90.00$ $\mathrm{mm}$ ), which was found to be significantly superior to all other media followed by oat meal agar $(83.3 \mathrm{~mm}), \mathrm{V}-8$ agar $(75.3 \mathrm{~mm})$, potato carrot agar $(74.70 \mathrm{~mm})$, Czapek's malt agar $(72.00 \mathrm{~mm})$ and potato dextrose agar $(66.7 \mathrm{~mm})$.

The least radial growth was recorded in Richards' agar $(64.7 \mathrm{~mm})$. Potato dextrose agar $(66.7 \mathrm{~mm})$ and Richards' agar $(64.7 \mathrm{~mm})$ were on par with each other. Further same on par results were found for V-8 agar $(75.3 \mathrm{~mm})$ and potato carrot agar $(74.70 \mathrm{~mm})$. The non synthetic / semi synthetic media recorded maximum growth compared to synthetic media.

Mycelium colour varied from white to light gray. The growth varied from flat to sparse. Pigmentation in the media also varied from brownish yellow to gray (Table 1 and Fig. 4). Spores were not produced in any media used for study.

\section{Cultural characteristics of $\boldsymbol{P}$. corticolum on different liquid media}

The experiment was conducted to ascertain the period for the maximum growth of the fungus by dry mycelial weight method, using two liquid media viz., potato dextrose broth and Richards' broth, starting from the $2^{\text {nd }}$ day to $20^{\text {th }}$ day. The results obtained are presented in the table 2 and figure 5 .

It is evident from the data that there were significant differences in the different incubation periods. Dry mycelial weight of $P$. corticolum recorded gradual increase in potato dextrose broth and Richards' broth, starting from second day $(33.67 \mathrm{mg}$ and 79.33 mg respectively) and reached peak growth on $14^{\text {th }}$ day $(442.33 \mathrm{mg}$ and $538.00 \mathrm{mg}$ respectively ) and remained significantly superior to remaining treatments. Later the dry mycelial weight declined to reach 292.67 $\mathrm{mg}$ and $401.00 \mathrm{mg}$ respectively on $20^{\text {th }}$ day of incubation. Mean dry mycelial weight of $P$. corticolum recorded maximum (490.17 $\mathrm{mg}$ ) on $14^{\text {th }}$ day of incubation. The dry mycelial weight on $12^{\text {th }}$ and $16^{\text {th }}$ day in potato dextrose broth remained on par with dry mycelial weight on $20^{\text {th }}$ day in Richards' broth. Similarly on par results were recorded on $14^{\text {th }}$ day in potato dextrose broth and $10^{\text {th }}$ and $18^{\text {th }}$ day of incubation in Richards' broth.

The description of typical black banded disease symptoms observed in this study, were in accordance to previous workers Reddy et al. (1961); Om Prakash and Srivastava (1987); Mukherjee and Litz (2009) and Patil and Dangat (2012). Peziotrichum corticolum (Massee) Subramanian was isolated and pure cultured. Identification of the same fungus was confirmed on the basis of morphology and pathogenicity in accordance with the description given by Subramanian (1956); Mukherjee and Litz (2009) and Patil and Dangat (2012). 
Table.1 Cultural characteristics of Peziotrichum corticolum on different solid media

\begin{tabular}{|c|c|c|c|c|c|c|}
\hline \multirow[b]{2}{*}{$\begin{array}{l}\text { Sl. } \\
\text { No. }\end{array}$} & \multirow[b]{2}{*}{$\begin{array}{c}\text { Different } \\
\text { Media }\end{array}$} & \multicolumn{5}{|c|}{ Colony characters } \\
\hline & & $\begin{array}{c}\text { Radial } \\
\text { growth } \\
(\mathbf{m m})^{\#} \\
(12 \text { DAI })\end{array}$ & Colour & $\begin{array}{l}\text { Type of } \\
\text { growth }\end{array}$ & Pigmentation & Margin \\
\hline 1. & $\begin{array}{l}\text { Host extract } \\
\text { dextrose } \\
\text { agar }\end{array}$ & 90.0 & White & $\begin{array}{l}\text { Flat growth } \\
\text { circular }\end{array}$ & White & $\begin{array}{l}\text { Sparse } \\
\text { Smooth }\end{array}$ \\
\hline 2. & $\begin{array}{l}\text { Oat meal } \\
\text { agar } \\
\text { medium }\end{array}$ & 83.3 & $\begin{array}{l}\text { Grayish } \\
\text { off white }\end{array}$ & $\begin{array}{l}\text { Flat growth } \\
\text { irregular }\end{array}$ & Gray & Smooth \\
\hline 3. & $\begin{array}{l}\text { Potato } \\
\text { carrot agar }\end{array}$ & 74.7 & White & $\begin{array}{l}\text { Flat growth } \\
\text { circular }\end{array}$ & Gray & $\begin{array}{l}\text { Medium } \\
\text { Smooth }\end{array}$ \\
\hline 4. & $\begin{array}{l}\text { Potato } \\
\text { dextrose } \\
\text { agar }\end{array}$ & 66.7 & White & $\begin{array}{l}\text { Flat growth } \\
\text { circular }\end{array}$ & White & Smooth \\
\hline 5. & V-8 agar & 75.3 & $\begin{array}{l}\text { Yellowish } \\
\text { White }\end{array}$ & $\begin{array}{l}\text { Flat growth } \\
\text { circular }\end{array}$ & Yellow & $\begin{array}{c}\text { Sparse } \\
\text { Smooth }\end{array}$ \\
\hline 6. & $\begin{array}{l}\text { Czapek's } \\
\text { malt agar }\end{array}$ & 72.0 & White & $\begin{array}{l}\text { Flat growth } \\
\text { irregular }\end{array}$ & White & Irregular \\
\hline 7. & $\begin{array}{l}\text { Richards' } \\
\text { agar }\end{array}$ & 64.7 & White & $\begin{array}{c}\text { Sparse } \\
\text { irregular }\end{array}$ & Yellow & $\begin{array}{l}\text { Sparse } \\
\text { Irregular }\end{array}$ \\
\hline \multicolumn{2}{|r|}{ S.Em. \pm} & 0.56 & & & & \\
\hline \multicolumn{2}{|c|}{ CD at $1 \%$} & 2.37 & & & & \\
\hline
\end{tabular}

\# Mean of three replications

DAI = Days after incubation

Table.2 Growth phase of Peziotrichum corticolum in liquid media

\begin{tabular}{|c|c|c|c|}
\hline \multirow{2}{*}{$\begin{array}{c}\text { Days after } \\
\text { incubation (DAI) }\end{array}$} & \multicolumn{2}{|c|}{ Dry mycelial weight (mg) ${ }^{\#}$} & \multirow{2}{*}{ Mean } \\
\cline { 2 - 3 } & Potato dextrose broth & Richards' broth $^{\prime}$ & \\
\hline 2 & 33.67 & 79.33 & 56.50 \\
\hline 4 & 65.67 & 189.00 & 127.33 \\
\hline 6 & 168.33 & 282.00 & 225.17 \\
\hline 8 & 256.67 & 361.33 & 309.00 \\
\hline 10 & 332.67 & 438.67 & 385.67 \\
\hline 12 & 394.33 & 512.33 & 453.33 \\
\hline 14 & 442.33 & 538.00 & 490.17 \\
\hline 16 & 400.67 & 483.00 & 441.83 \\
\hline 18 & 328.67 & 444.67 & 386.67 \\
\hline 20 & 292.67 & 401.00 & 346.83 \\
\hline Mean & 271.57 & 372.93 & \\
\hline Source & DAI (A) & Broth (B) & $\mathbf{A} \times \mathbf{B}$ \\
\hline S.Em \pm & 1.63 & 0.73 & 2.30 \\
\hline CD at 1\% & 6.23 & 2.79 & 8.82 \\
\hline
\end{tabular}

${ }^{\#}$ Mean of three replications 
Fig.1 Symptoms of black banded disease of mango. a) on new branches; b) on old branches; c) on midrib and veins of leaves; d) close view of black velvety symptoms; e) on leaf petiole and f) microscopic view of velvety growth

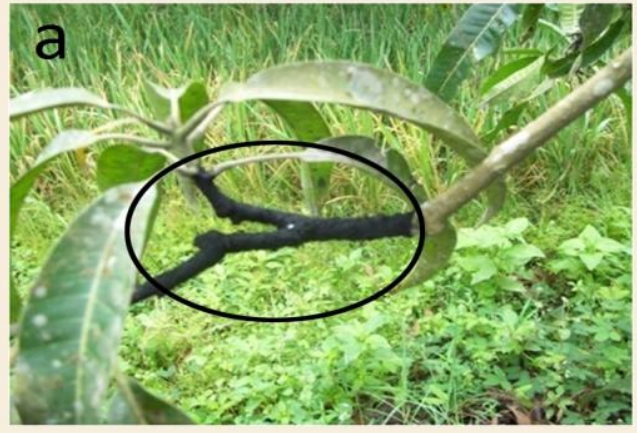

a) On new branches

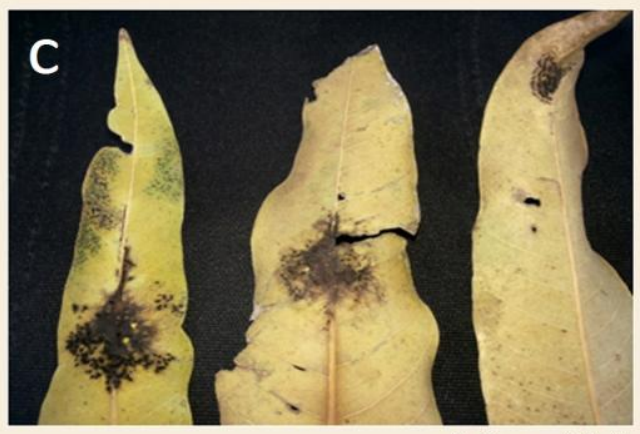

c) On midrib and veins of leaves

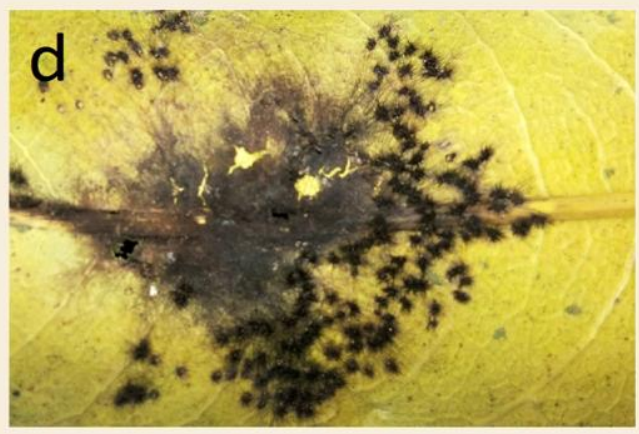

d) Close view of black velvety symptoms

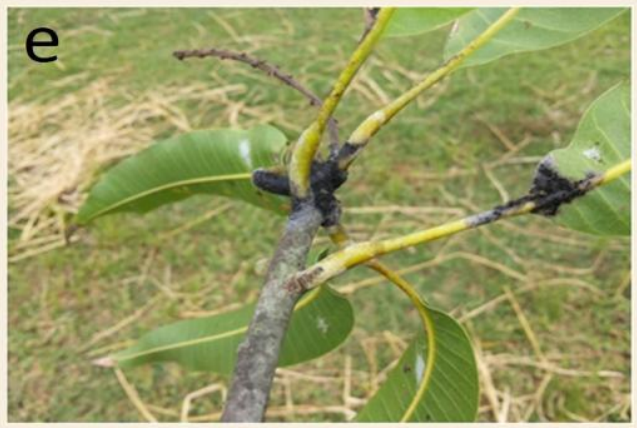

e) On leaf petiole

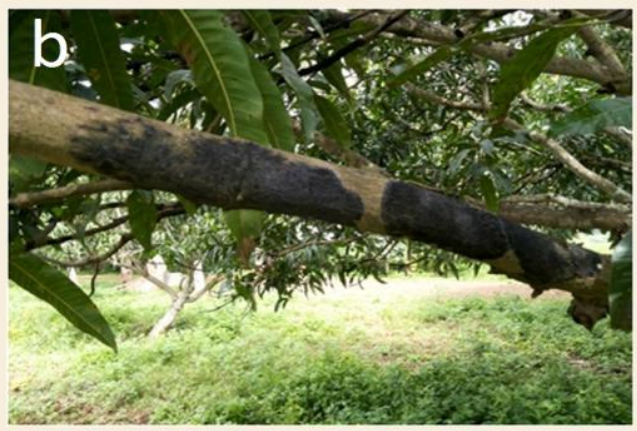

b) On old branches
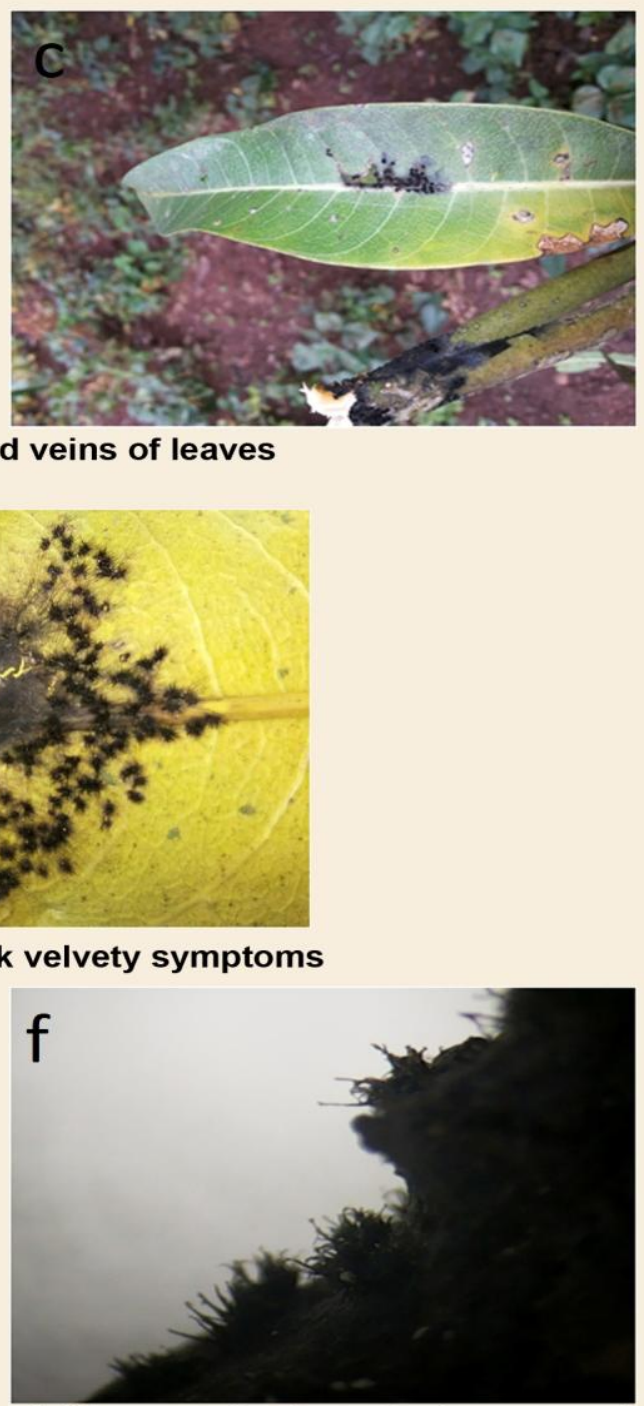

f) Microscopic view of velvety growth 
Fig.2 Proving pathogenicity. a) Inoculated plant (injury + inoculum + sterile distilled water) and

b) Initial stage of symptom expression
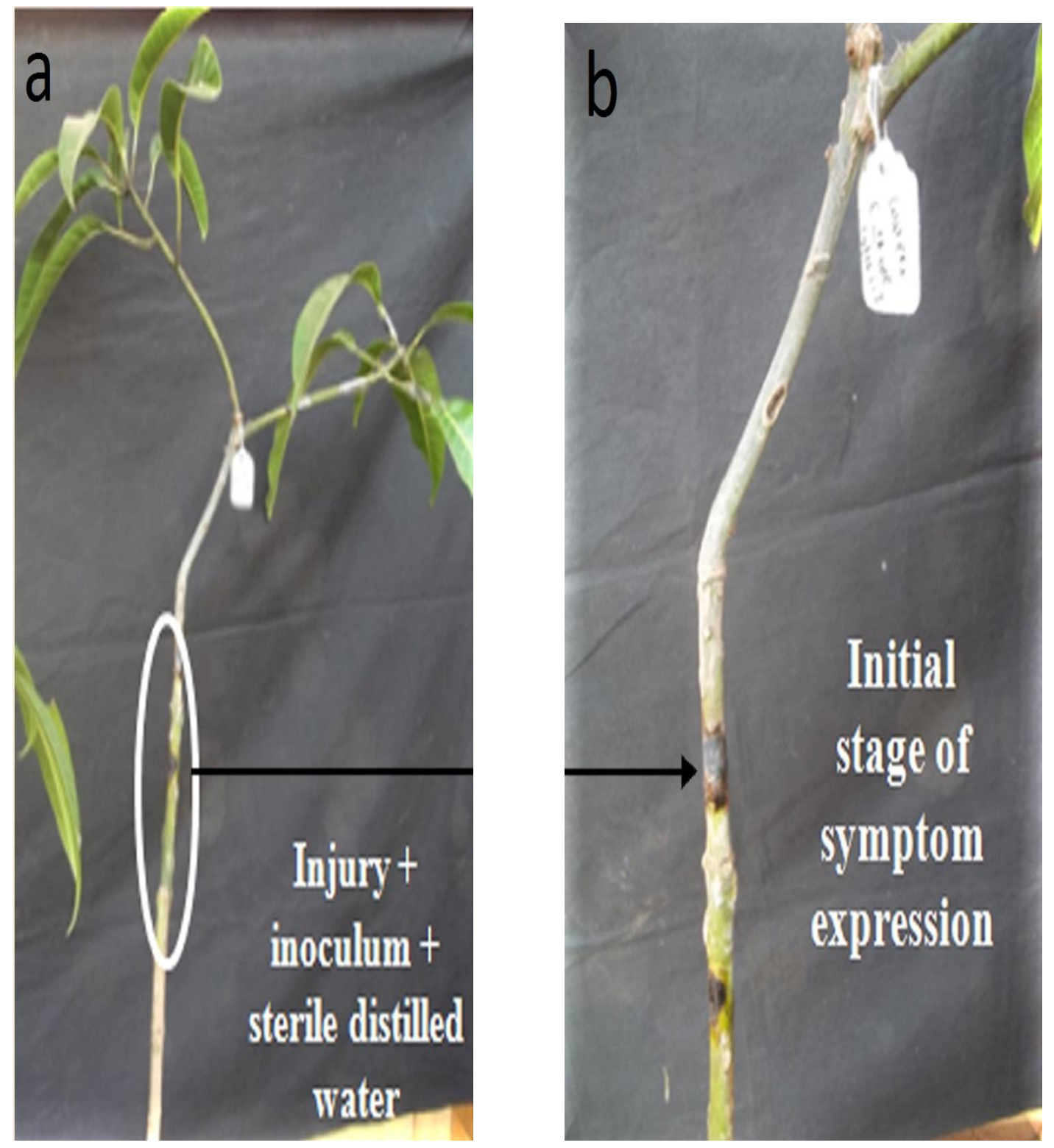
Fig.3 Culture and morphology of Peziotrichum corticolum. a) culture up to 20 days; b) culture after 20 days c) spores; d) mycelium and e) germinated spores in agar plate
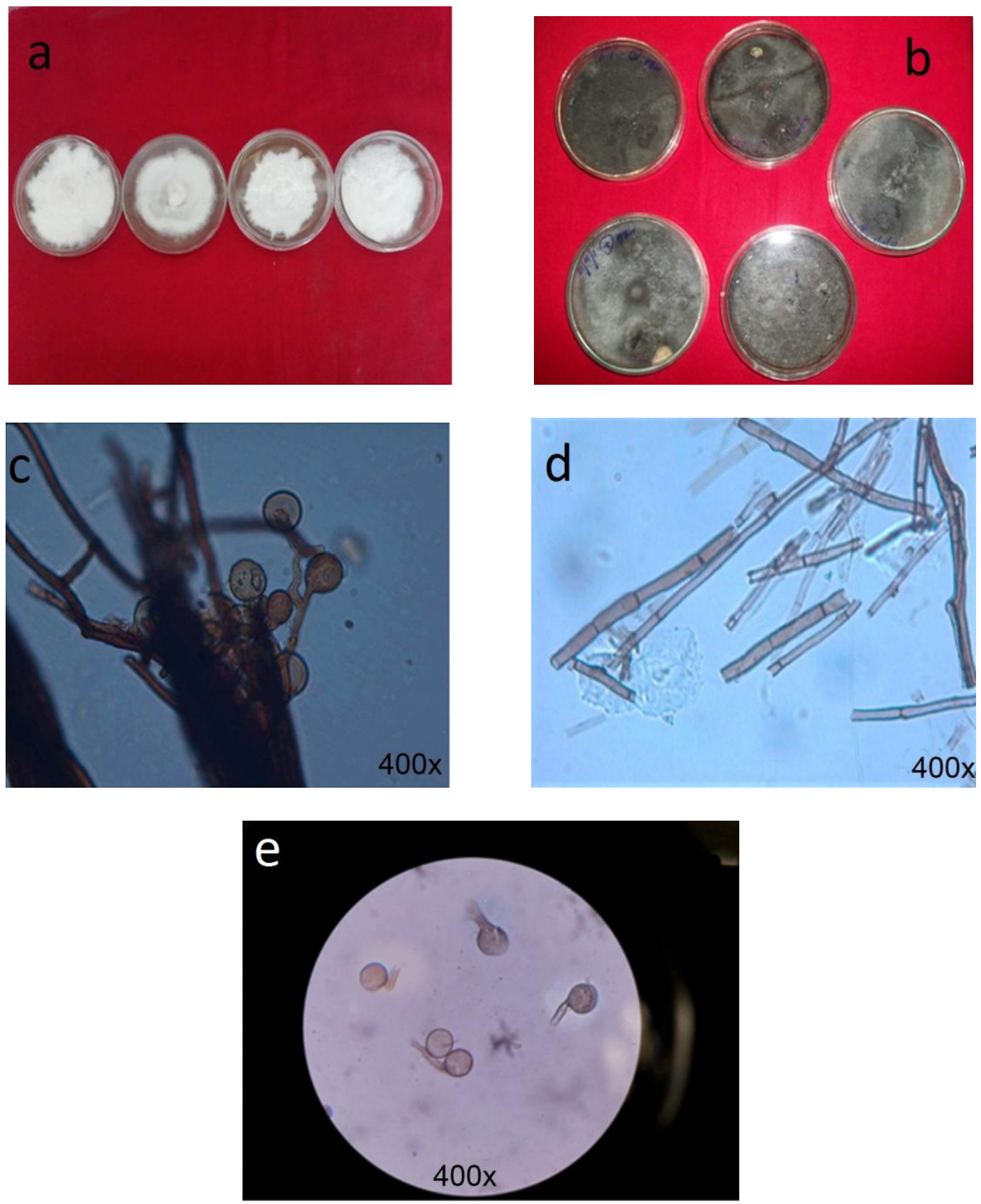
Fig.4 Growth of Peziotrichum corticolum on different solid media after 12 days. 1) Host extract dextrose agar, 2) Potato dextrose agar, 3) Czapeck’s malt agar, 4) Richards' agar, 5) Oat meal agar, 6) V-8 agar and 7) Potato carrot agar

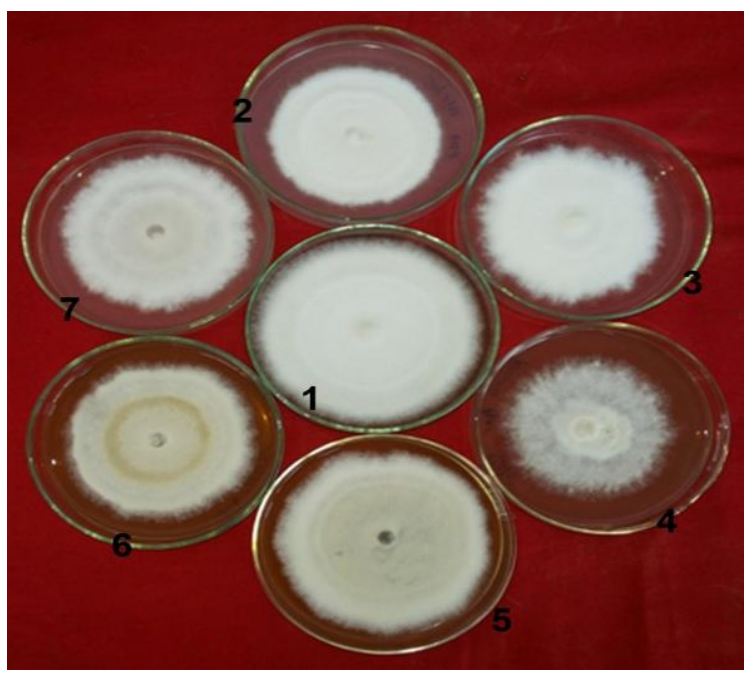

\section{Pathogenicity}

Pathogenicity test was proved following Koch's postulates. As this is the first attempt towards proving pathogenicity against $P$. corticolum, no supporting reference is available for conformity or for comparison.

\section{Identification}

The study on morphological characteristics of Peziotrichum corticolum indicated, septate hyphe measuring $3.2-6.82 \mu$ in width, brown in colour. Conidia were single celled, pale brown, globose, smooth- walled; 11.25 - $17.36 \mu$ in diameter. The findings are in agreement with the findings of earlier workers (Subramanian, 1956; Mukherjee and Litz, 2009; Patil and Dangat, 2012). Based on the mycelial and spore morphology, the fungus under study was identified as Peziotrichum corticolum (Massee) Subramanian.

\section{Cultural studies}

Fungi secure food and energy from the substrate upon which they live in nature. In order to culture the fungus in the laboratory it is necessary to furnish those essential elements and compounds in the medium for their growth and other life processes. Neither all media are equally good for all fungi, nor there any universal substrate or artificial medium upon which all fungi can grow. So, different media including, non synthetic, semi-synthetic and synthetic were tried for $P$. corticolum.

\section{Cultural characteristics of $\boldsymbol{P}$. corticolum on different solid media}

Among the non or semi-synthetic and synthetic media used for growth and sporulation of $P$. corticolum, maximum radial growth was recorded on host extract dextrose agar (90.00 $\mathrm{mm}$ ) and least radial growth was recorded in Richards's agar $(64.7 \mathrm{~mm})$. Sporulation was not observed in any media, used for study. Maximum radial growth of the fungus on host extract dextrose agar may be due to host's cell constituents in the media, supporting good fungal growth. Further Naqvi (2004) reported maximum radial growth of Pestalotiopsis mangiferae causing grey blight of mango on host extract agar.

Cultural characteristics of $\boldsymbol{P}$. corticolum on different liquid media 
Mean dry mycelial weight of $P$. corticolum was recorded maximum $(490.17 \mathrm{mg})$ on $14^{\text {th }}$ day of incubation. Maximum dry mycelial weight of $P$. corticolum was recorded on $14^{\text {th }}$ day in both liquid media namely potato dextrose broth and Richard's broth (442.33 $\mathrm{mg}$ and $538.00 \mathrm{mg}$ respectively). Later the dry mycelial weight declined to reach $292.67 \mathrm{mg}$ and $401.00 \mathrm{mg}$ respectively on $20^{\text {th }}$ day of incubation which may have been due to autolysis of the mycelium, accumulation of toxins and exhaustion of nutrients in the medium after incubation for optimum number of days.

Vinod and Benagi (2009) also reported autolysis of the fungus Colletotrichum gloeosporioides after optimum days of incubation. Further Ashoka (2005) reported that dry mycelial weight of Colletotrichum gloeosporioides was obtained more in Richards' broth $(394.00 \mathrm{mg})$ than potato dextrose broth (378.00 mg).

\section{References}

Ainsworth, G.C. 1971. Ainsworth and Bisby's dictionary of the fungi. VI Edition. England: Commonwealth Mycological Institute, Kew, Survey, p. 663.

Ashoka, S. 2005. Studies on fungal pathogens of vanilla with special reference to Colletotrichum gloeosporioides (Penz.) Penz. and Sacc. M.Sc. (Agri.) Thesis, Uni. Agric. Sci., Dharwad, India.

Hughes, S.J. 1980. New Zealand Fungi 29. Rhinocladium Sacc. et March. New Zealand J. Bot., 18: 163-172.

Mukherjee, S.K., Litz, R.E. 2009. Foliar, Floral and Soilborne Diseases. In: The Mango: Botany, Production and Uses $2^{\text {nd }}$ ed.
(R.E. Litz, ed), p. 246.

Naqvi, S.A.M.H. 2004. Diseases of fruits and vegetables, Kluwer Academic Publishers, Dordrecht.

National Horticulture Database 2014. http://nhb.gov.in/area-pro/ NHB Database 2015. (retrieved on 21.9.2015).

Om Prakash and Srivastava, K.C. 1987. Mango disease and their management. A World Review, Today and Tommorrow, p.175.

Om Prakash: Diseases of Mango. In: Mango Cultivation (Ed. Srivastava, R. M.). International Book Distributing Co. Lucknow, 1998; Pp. 409- 424.

Pandey, S.N. and Dinesh, M.R. 2010. Mango. New Delhi: Indian Council of Agricultural Research.

Patil, A.R. and Dangat, B.T. 2012. Sustainable and ecofriendly management of black banded disease of mango from Kolhapur, Maharashtra. Acta Biologica Indica, 1(1): 125-128.

Ploetz, R.C. and Om Prakash. 1997. Foliar, floral and soil borne diseases In: The mango, Botany, Production and Uses (Ed. Litz, R. E.). CAB International, London (U.K.), pp. 281-326.

Reddy, G.S., Govinda Rao, P. and Paparao, A. 1961. Black banded disease of mango. The Andhra Agril. J., 8(2): 120-123.

Subramanian, C.V. 1956. Hyphomycetes - II. $J$. Ind. Bot. Soc., 35(4): 446-494.

Tuite, J. 1969. Plant Pathological MethodsFungi and Bacteria. U.S.A.: Burgress publishing Co, Minneapolis, p. 239.

Vinod, T. and Benagi, V.I. 2009. Studies on cultural and nutritional characters of Colletotrichum gloeosporioides, the causal organism of papaya anthracnose. Karnataka J. Agric. Sci., 22(4): 787-789.

\section{How to cite this article:}

Chirag Gautam, H. Virupaksha Prabhu and V.B. Nargund. 2017. Morphological and Cultural Studies of Peziotrichum corticolum (Massee) Subramanian Causing Black Banded Disease of Mango. Int.J.Curr.Microbiol.App.Sci. 6(4): 1290-1300.

doi: https://doi.org/10.20546/ijcmas.2017.604.158 